\title{
Dracula - non omnis moriar Facts and myths from the life of Vlad III the Impaler
}

\section{STRESZCZENIE}

\section{Dracula - non omnis moriar. Fakty i mity z życia Włada III Palownika}

T iemal każdy słyszał o okrutnym Draculi, wampirze wychodzącym z grobu 1 i żywiącym się krwią żywych, by żyć wiecznie. Kim jednak był pierwowzór postaci, która na stałe zadomowiła się we współczesnej kulturze popularnej? Aby odpowiedzieć na to i inne pytania, w niniejszym artykule opisane zostana najważniejsze fakty $z$ życia wołoskiego hospodara Włada III Palownika. Następnie przedstawione zostana najbardziej znane legendy o Draculi, majace wpływ na stale rozrastający się mit transylwańskiego arystokraty-wampira, zrodzonego w XIX w. na kartach powieści irlandzkiego pisarza Brama Stokera.

Słowa kluczowe: Dracula, Wład III Palownik, Wołoszczyzna, Bram Stoker

\section{Abstract}

\begin{abstract}
Amost everyone has heard of the cruel Dracula, the vampire coming out of the A grave and feeding on the blood of the living to live forever. But who was the prototype of the character who has permanently settled in the contemporary popular culture? In order to answer this and other questions, the presented article will describe the most important facts from the life of the Wallachian voivode, Vlad III the Impaler. Then, the most famous legends about Dracula will be presented, as they still influence the ever-growing myth of the Transylvanian vampire aristocrat, born in the nineteenth century on the pages of the novel by Irish writer Bram Stoker.
\end{abstract}

Keywords: Dracula, Vlad III the Impaler, Wallachia, Bram Stoker 


\section{Introduction}

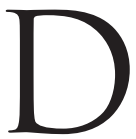

racula - Prince of Darkness, powerful vampire, bloody beast and terrifying creature described by the Irish writer Bram Stoker in his book of 1897 that quickly conquered all Europe ${ }^{1}$. When looking for an idea for a novel, Stoker carefully analysed the library's sources and had numerous interviews with the Hungarian orientalist, Arminius Vamberry. Thus he found information about the prince Dracula who ruled in Wallachia ${ }^{2}$ in the fifteenth century and, according to some researchers, also the story of the controversial Elizabeth Báthory ${ }^{3}$, a Hungarian countess with sadistic tendencies. As in times of the Victorian England, death and disease were surrounded by a fog of superstition and all over the world vampire legends were an attempt to explain things incomprehensible to humans, the Irish writer decided to portray Dracula as a creature coming out of the grave and feeding on the blood of the living ${ }^{4}$. We may assume that an essay by Emily Gerard entitled Transylvanian superstitions ${ }^{5}$ was the inspiration for the

${ }^{1}$ See B. Stoker, Dracula, Hertfordshire 2000; idem, Dracula's Guest and Other Stories, Hertfordshire 2006.

2 The homeland of the book character is not Wallachia, but the bordering Transylvania. There is a hypothesis that Bram Stoker twisted some of the facts about the life of Vlad III the Impaler heard in the stories told by Arminius Vambery. See M. Cazacu, Drakula, $2^{\text {nd }}$ ed., transl. B. Biały, Warszawa 2021, pp. 257-258. Discussions on the alleged relationship between Stoker's character and the historical Vlad Dracula can be found, among others, in the book by R.T. McNally, R. Flore s cu, In Search of Dracula: A True History of Dracula and Vampire Legend, Greenwich 1972.

${ }^{3}$ More information can be found in A. Bartosiewicz, Elisabeth Báthory a true story, "Przeglad Nauk Historycznych" 2018, vol. XVII, No. 3, pp. 103-122.

${ }^{4}$ In Romanian folklore they believed in strigoi and moroi (not vampires), which are undead souls that could return from the afterlife to suck energy (life, soul and, interestingly, much less often - blood) from a loved one. On the other hand, a vampire, according to Slavic folk beliefs, is the spirit of a deceased person or a living corpse that torments the living by drinking blood, eating their meat, choking, etc. See B. Baranowski, W kręgu upiorów i wilkołaków, Łódź 1981, pp. 51-52; P. Johnson, Count Dracula and the Folkloric Vampire: Thirteen Comparisons, "Journal of Dracula Studies" 2001, vol. III, issue 1, p. 3; C. Ro b otycki, Wampiry. Od wierzeń ludowych do filmowych fantomów, "Konteksty" 1992, No. 3-4, p. 145; J. Strzelczyk, Mity, podania i wierzenia dawnych Słowian, Poznań 1998, p. 219; P. Zych, W. Vargas, Bestiariusz słowiański. Część pierwsza i druga, Olszanica 2018 , pp. 396-397.

${ }^{5}$ E. Gerard, Transylvanian Superstitions, "The Nineteenth Century" 1885, vol. XVIII, pp. 128-144. 
vampire thread in Stoker's famous novel. Studying the materials contained there, he probably discovered, among others, effective methods in the fight against vampires, such as deterring with garlic, sprinkling holy water, staking through the heart of a dead or cutting off the head and burning the corpse ${ }^{6}$.

Since then, Dracula's story has been filmed over 200 times $^{7}$. But who was the prototype of the character who has permanently settled in the contemporary popular culture? And has Vlad Dracula ever been accused of vampirism? In order to answer these and other questions, this article will describe the most important historical facts from the life of the Wallachian voivode, Vlad III the Impaler. Then, the most famous legends about Dracula will be presented, as they still influence the ever-growing myth of the Transylvanian vampire aristocrat, born in the nineteenth century on the pages of Bram Stoker's novel.

\section{The political situation in Wallachia in the first half of the $15^{\text {th }}$ century}

Wallachia is part of today's southern Romania, lying between the Danube and the Carpathians. In the fifteenth century it bordered Hungary, Transylvania, Moldova, Serbia and the Ottoman Empire (see Fig. 1). Practically until the mid-fifteenth century, the national and cultural character of the Wallachian state was clearly Romanian and closely related to the Orthodox Church. Politically, from the very beginning of its independent existence, the principality was associated with Catholic Hungary. However, at the turn of the fourteenth and fifteenth centuries, during the reign of voivode Mircea

${ }^{6}$ E. Miller, The Question of Immortality: Vampires, Count Dracula, and Vlad the Impaler, "Journal of Dracula Studies" 2002, vol. IV, issue 1, p. 1.

7 The most famous adaptations include, among others, Nosferatu. A Symphony of Horror (dir. F.W. Murnau, 1922), Dracula (with Bela Lugosi, dir. T. Browning, 1931), Horror of Dracula (with Christopher Lee, dir. T. Fisher, 1958), The Fearless Vampire Killers (dir. R. Polański, 1967), Nosferatu the Vampyre (with Klaus Kinski, dir. W. Herzog, 1979), Bram Stoker's Dracula (with G. Oldman, dir. F.F. Coppola, 1992) or Dracula Untold (dir. G. Shore, 2014). According to M. Grabias, especially in the last two titles, one can find clear references linking the main character with the historical Wallachian prince, which clearly shows how the aforementioned theory of McNally and Florescu is rooted in the imagination of creators and popular culture. M. Grabias, Dracula-nowe perspektywy badawcze (recenzja), "Perspektywy Kultury" 2019, No. 25, p. 195. 
the Elder (1386-1418), it had to face the growing influence of the rapidly expanding Turkish state, to which it began to pay tribute in 1417. After the death of Mircea the Elder, a fierce fratricidal fight for the Wallachian throne broke out, which lasted almost a century and additionally weakened the position of Wallachia in relation to both powerful neighbours ${ }^{8}$.

In such circumstances, at the beginning of the fifteenth century (after the death of his elder brothers, Michael I and Radu II the Empty Head), the third son of Mircea the Elder, Vlad II Dracul, called the Dragon ${ }^{9}$, appeared on the political horizon. As a pupil of the Hungarian king Sigismund of Luxembourg, he was admitted in 1431 to the Order of the Dragon, which was established as a secular military-religious community to defend Christianity and fight the Ottomans. Vlad the Dragon was admitted to this elite order for strictly political reasons. At that time, the voivode of Wallachia, Dan II (son of Dan I, who ruled before Mircea the Elder), died and the Hungarian court was preparing Vlad the Dragon for his successor. Thus it was decided in advance to bound him by a special oath of allegiance to king Sigismund. However, before Vlad Dracul managed to reach Wallachia from Hungary, Alexander I Aldea, who claimed to be Mircea the Elder's illegitimate son, took power there. Therefore, only after the latter's death in 1436, previously occupied with the affairs of the Hussites and wars in Europe Sigismund of Luxemburg gave Vlad II armed support, and the latter became a new voivode of Wallachia ${ }^{10}$.

${ }^{8}$ I. Czamańska, Drakula, wampir, tyran czy bohater?, Warszawa 2013, pp. 11-15.

9 Due to the constant use of the dragon as an emblem, he was initially called the Dragon (lat. Draco, rom. Drac), which after adding the Romanian masculine article -ul turned into the Romanian Dracul, meaning Devil. However, during the lifetime of Vlad II, the nickname had positive connotations. Only during the reign of his son, Vlad III, after further transformations, the family began to bear the surname Dracula, which was associated with evil and cruelty. I. Czamańska, op. cit., p. 28; C. Reza ch evici, From the Order of the Dragon to Dracula, "Journal of Dracula Studies" 1999, vol. I, issue 1, p. 5.

10 A. Michalewska, Vlad Palownik. Prawdziwy Drakula, https://www. granice.pl/publicystyka/wlad-palownik-vlad-drakula-dracula-historiaprawdziwa/1134/1 (accessed: 15 VII 2021); B.G. Sala, W górach przeklętych. Wampiry Alp, Rudaw, Sudetów, Karpat i Bałkanów, Olszanica 2016, p. 165. 


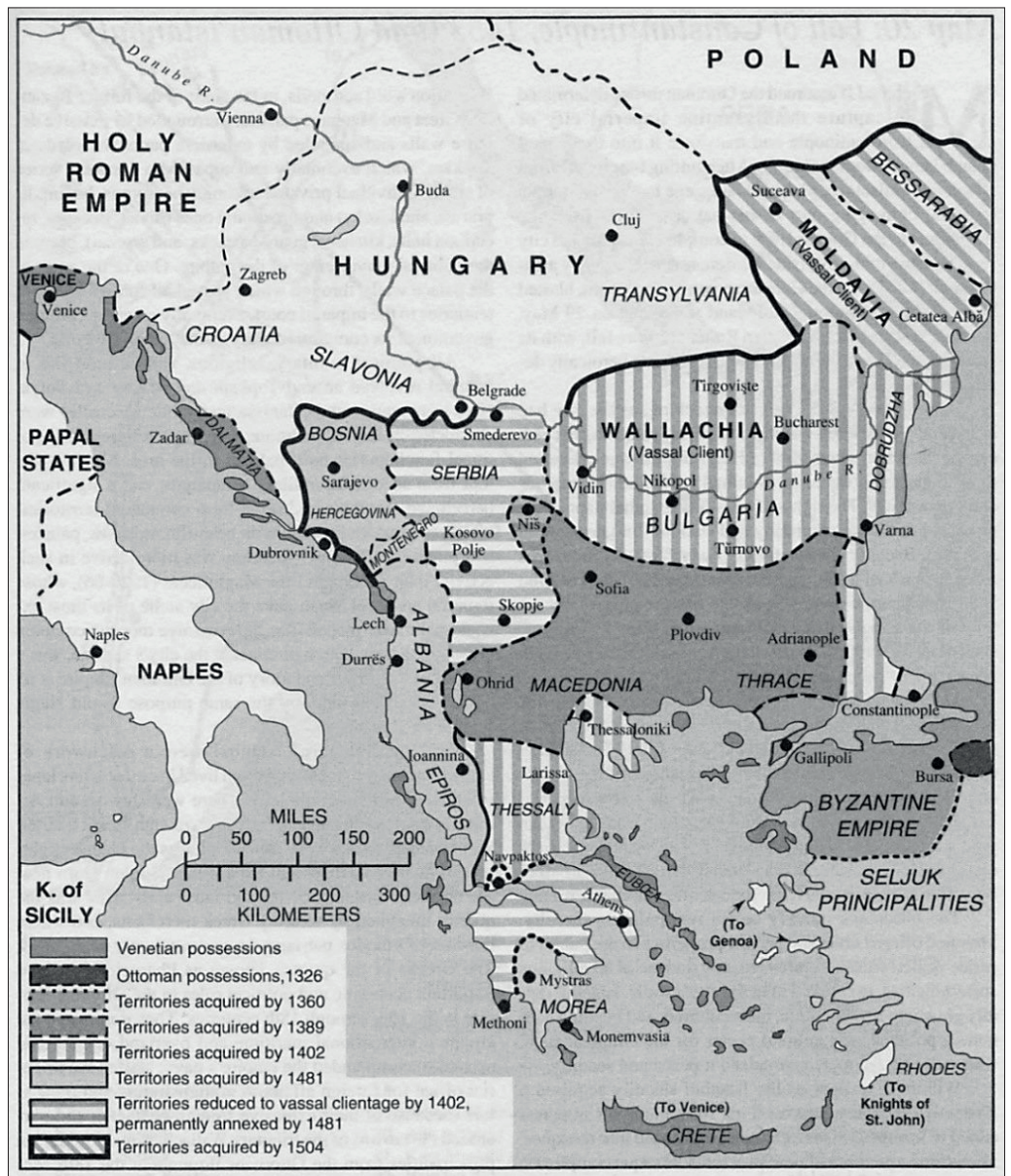

1. Map of Wallachia and the surrounding area

(Source: D. Hupchick, H. Cox, The Palgrave Concise Historical Atlas of the Balkans, New York 2001)

The same year, Turkish troops entered Wallachia, and the new ruler of the principality started negotiations with Murad II. As it turned out, Vlad the Dragon was a pragmatist. The Turks were close, and the emperor was far away. Therefore, when Sigismund of Luxemburg died in 1437, and Albert the Magnanimous succeeded him, Vlad II granted the Turks military aid against the new Hungarian king ${ }^{11}$. In the following years, the political situation

${ }_{11}$ M. V ors in o, The Dragon, the Raven and the Ring, "Journal of Dracula Studies" 2003, vol. V, issue 1, pp. 5-6. 
in Hungary changed significantly. In November 1439, Albert the Magnanimous died unexpectedly and was replaced by the Polish king, Władysław III of Varna. However, before he could come from Krakow and take power, Queen Elizabeth, widow of Albert the Magnanimous, granted the crown of Hungary to her posthumous son, Ladislaus $\mathrm{V}$ the Posthumous. Civil war began in Hungary. At the same time, the Hungarian-Turkish conflict also intensified, in which one of the most influential members of the Order of the Dragon, John Hunyadi, played a significant role as the commander of the Hungarian forces ${ }^{12}$.

After the victory over the Ottoman army on the Ialomita in 1442, John Huynadi, supported by the king of Hungary, placed the son of Dan II, Basarab II, a faithful ally in the fight against the Turks, on the Wallachian throne. In this situation, deprived of the throne, Vlad Dracul decided to seek support from Murad II. Contrary to his expectations, however, he was imprisoned in the Gallipoli fortress, from which the sultan released him only two years later, fearing that the then alliance between Hungary and Wallachia could seriously threaten Turkey's interests. Vlad the Dragon returned to Wallachia accompanied by an armed Turkish detachment and reclaimed the throne, taking the life of his predecessor, Basarab II. At the same time, two younger sons of Vlad II, Radu (later Radu III the Handsome) and Vlad (later Vlad III T,epeş) were sent to Eğrigöz as hostages and guarantors of the treaty for the independence of Wallachia. For this reason, among others, Vlad II, still a sworn member of the Order of the Dragon, did not personally participate in the battle of Varna, which was lost by the anti-Turkish coalition on November 10,1444, sending his son Mircea as his replacement. He himself joined the ongoing conflict over the Moldovan throne instead. As a result, Hungary was forced to intervene almost simultaneously in both Romanian countries. They provided, inter alia, support for the pretender to the Wallachian throne, the son of Dan II, Dan III the Younger, and inspired the outbreak of an uprising against Vlad II and his co-ruling eldest son, Mircea. The latter was murdered in a revolt by the inhabitants of the capital, Tîrgovişte, while Vlad the Dragon was killed in early 1447 in Bălteni. The rule in Wallachia was taken over by Dan III, thus

${ }_{12}$ M. Torz, Od wołoskiego hospodara po ikone popkultury, "Archeologia Żywa" 2018, No. 4(70), p. 70. 
starting a new phase of the struggle for the Wallachian throne fought by the next generation of descendants of Dan I and Mircea the Elder ${ }^{13}$.

\section{The Reign of Vlad III the Impaler}

Less than a year after the events described above, the sultan released Vlad and Radu. The latter remained in Turkey, while 17-year-old Vlad returned to Wallachia and, with Ottoman help, regained his paternal throne as Vlad III Dracula. However, after less than two months, he was deposed by John Hunyadi ${ }^{14}$, who was acting regent of Hungary at that time, and his supporters, as a result of which he had to save himself by fleeing to nearby Moldova, where he stayed for the next several years with short breaks ${ }^{15}$.

Vlad III the Impaler (rom. Vlad III Țepeş) was born in Sighișoara in the principality of Transylvania in 1431, as the second son of Vlad II the Dragon. Under the care of a boyar tutor, he spent his childhood and youth there, until 1444, when he spent four years with his younger brother Radu III as a hostage at the Turkish court. He inherited the nickname Drăculea from his father, translated as "Son of the Dragon" or "Son of the Devil", although during his reign he was also called Prince the Impaler (rom. Tepeş, tur. Kaziklu Bey $)^{16}$. And this is how the papal legate Nicholas of Modrussy

13 I. Czamańska, op. cit., pp. 32-33, 44; R. F1orescu, R. McNa11y, Dracula: A Biography of Vlad the Impaler, New York 1973, p. 106; Vlad Tepes: Tyrant or Misunderstood?, https: / / owlcation.com/humanities/Vlad-Tepes-Tyrant-or-Misunderstood (accessed: 22 VI 2021).

${ }^{14}$ After the death of Władysław III of Varna in the battle of Varna, Hungarian magnates chose Ladislaus V the Posthumous as their king, but emperor Frederick III refused to comply with the demands and for the next two years, Hungary was ruled by the so-called Council of Seven. After its dissolution by the Sejm in 1446, John Hunyadi assumed power on behalf of Ladislaus the Posthumous. W. Fe1czak, Historia Wegier, Wrocław-Warszawa-Kraków 1966, p. 89.

15 S. Andreescu, Vlad Țepeş (Dracula). Intre legendă şi adevăr istoric, Bucharest 1998, p. 14; P. Dan, Psycho-biographical considerations about Vlad the Impaler also known as Dracula, p. 14, https://www.academia.edu/10342218/ Psycho-biographical_considerations_about_Vlad_the_Impaler_also_known_as_ Dracula (accessed: 19 VII 2021); K. Go nerski, Vlad Tepes: prawdziwa historia Księcia Draculi, http://www.horror.com.pl/publicystyka/art.php?id=62 (accessed: 1 VII 2021).

16 J.G. Melto n, A. Hornick, The Vampire in Folklore, History, Literature, Film and Television. A Comprehensive Bibliography, Jefferson, NC 2015, p. 55; C. Te odorescu, L.S. Szemkovics, R. Radu, From Vlad Țepeş - Wallachian ruler - to 
described his appearance: "He was not very tall, but very stocky and strong, with a cruel and terrible appearance, a long straight nose, distended nostrils, a thin and reddish face in which the large wide-open green eyes were framed by bushy black eyebrows, which made them appear threatening. His face and chin were shaven but for a moustache. The swollen temples increased the bulk of his head. A bull's neck supported the head, from which black curly locks were falling to his wide-shouldered person" 17 .

When in May 1453, sultan Mehmed II ${ }^{18}$ conquered Constantinople, a new Hungarian-Turkish conflict broke out. Because of Dan III's two-faced attitude, he fell out of favour, suspected of supporting the Turks. The Hungarians decided to restore to the Wallachian throne Vlad III Dracula, who, while previously in Transylvania, managed to gain the trust of John Hunyadi. In 1456, he gave additional proof of his loyalty to the Hungarian regent by supporting his troops in an expedition to the besieged Belgrade. The relief not only saved the city, but also led to the defeat of Turkish troops. After the battle of Belgrade (July 4-22, 1456), an epidemic of plague broke out, as a result of which Hunyadi lost his life, and the Turks were forced to retreat. In this situation, in the same year, Vlad Dracula decided to take power from Dan III, who lost in the fight not only the throne, but later (in the Holy Week of 1460) also his life ${ }^{19}$.

After his coronation to the prince of Wallachia, Vlad III chose a twelve-person council and initiated a strong-arm regime. In 1457, he dealt with the Saxons from Sibiu and Braşov, who had previo-

Dracula. Conclusive documents regarding his name and "fame", "Quaestus. Multidisciplinary Research Journal” 2018, No. 12, p. 56.

17 Nicholas of Modrussy as quoted in: A. Marcu, Riflessi di storia rumena in opere italiane dei secoli XVI e XV, "Ephemeris Dacoromana" 1923, vol. I, pp. 371-375; see also P. Dan, op. cit., p. 15.

18 Mehmed II the Conqueror was sultan of the Ottoman Empire twice. After the abdication of his father, Murad II, he ruled Turkey for only two years (1444-1446). He regained power only after his father's death in 1451, and ruled continuously until death in 1481. J. Reychman, Historia Turcji, Wrocław 1973, p. 52.

19 According to some sources, after capturing Dan III the Younger, Dracula had a grave dug for him and a Christian funeral ceremony was held, and then he beheaded him, while the bodies of the voivode's people who died in battle were impaled. As a result of these events, peace reigned between Wallachia and Transylvania, and these countries did not fall into any conflict until the fall of Vlad in late 1462. See M. Cazacu, op. cit., pp. 135, 138; B.G. Sala, op. cit., p. 167; M. Torz, op. cit., p. 69; K.W. Tre p tow, Vlad III Dracula: the Life and Times of the Historical Dracula, Portland 2000, p. 112. 
usly supported Vlad IV the Monk (the illegitimate son of Vlad II the Dragon) and Dan III the Younger, who were both claiming to the Wallachian throne ${ }^{20}$. On Easter 1459, in turn, he took revenge on the boyars who had killed his father and brother over a decade earlier. He invited them to a sumptuous feast in Tîrgovisste. Those who were directly responsible for the murder of his family were to have their throats cut. The others were sent on a journey to the mountains, where they were forced to murderous work on the construction of the Poenari castle. Thanks to this skilful move, Vlad Dracula not only avenged the deaths of the loved ones, but, above all, got rid of potential political opponents who could threaten his position. Other subsequent executions of rebellious and disloyal boyars and their families had economic reasons, too. The physical destruction of the entire family meant that its property was taken over by the voivode himself ${ }^{21}$.

Despite many internal enemies, the neighbourhood of Turkey turned out to be the greatest threat to the power of the Wallachian prince. When in 1459, Vlad refused to pay the tribute imposed on him two years earlier, Mehmed II's army invaded the lands of Wallachia in the spring of 1462. The sultan's late reaction to the disobedience of the Wallachian tributary should be explained by the political situation in Turkey at that time. In 1460, Mehmed II was seized in Morea, and in 1461, he fought in Asia Minor. At the beginning of the conflict, it was the Wallachian voivode who attacked Turkish territories, which exposed himself to retaliation by the sul$\tan ^{22}$. Vlad Dracula, however, turned out to be a bright and cunning strategist. He used the scorched earth policy. On his order, villages and settlements were burned, and wells and water reservoirs were poisoned to make it difficult for the sultan's army to march deep into the country ${ }^{23}$. On the night of June 16-17, 1462, in turn, the

${ }^{20}$ N. Stoicescu, Vlad Tepes' Relations with Transylvania and Hungary, [in:] Dracula. Essays on the Life and Times of Vlad the Impaler, ed. K.W. Treptow, New York 1991, pp. 84-85.

${ }^{21}$ I. Czamań ska, op. cit., p. 62; K. Rozwad ow ski, Wład III Palownik-Dracula, https://historia.org.pl/2009/10/05/wlad-iii-palownik-dracula/ (accessed: 1 VII 2021).

${ }^{22}$ Reporting to the King of Hungary on his Danube campaign, Dracula presented a record of 23,883 dead. Never before have the Turks suffered such great losses in such a short time. M. Cazacu, op. cit., p. 149.

${ }^{23}$ The destruction of towns, villages and border crossings, as well as the total depopulation of the area south of the Danube along the state border were also intended to reduce the number of strategic points where a Turkish invasion could 
voivode attacked the sultan's camp, having previously dressed his army in Turkish clothes. Surprised Turks started murdering each other and only thanks to their great numerical superiority they did not suffer a defeat. When, despite these actions, the Turkish army was still moving towards Tîrgovişte, Dracula decided to finally break the opponent's morale. The sultan's army encountered 20,000 impaled bodies. Apparently, there were not only the bodies of Turkish prisoners, but also of those of the Wallachian soldiers who had received in previous clashes wounds in the back ${ }^{24}$. The Greek historian Chalkokondyles described those events as follows: "The sultan's army entered into the area of the impalements, which was seventeen stades long and seven stades wide. There were large stakes there on which, as it was said, about twenty thousand men, women, and children had been spitted, quite a sight for the Turks and the sultan himself. The sultan was seized with amazement and said that it was not possible to deprive of his country a man who had done such great deeds, who had such a diabolical understanding of how to govern his realm and its people. And he said that a man who had done such things was worth much. The rest of the Turks were dumbfounded when they saw the multitude of men on the stakes. There were infants too affixed to their mothers on the stakes, and birds had made their nests in their entrails" 25.

After these events, the sultan ordered a retreat, and the Ports' troops moved east, bypassing Tîrgoviște. Soon after, the political emissaries of Mehmed II established contacts with the Wallachian opposition and put forward as a candidate for the throne the younger brother of Vlad Dracula, Radu the Handsome ${ }^{26}$. Importantly, in 1462, Wallachia, conflicted with Moldova ${ }^{27}$ and deprived of any external support, both from Hungary (suffering from a lack of

be expected. C. Smith, Vlad Țepeş, his military campaign against the Ottoman Empire in 1462, and the forging of a Romanian national identity, p. 13, https:// www.academia.edu/25642701/Vlad_\%C5\%A2epe\%C5\%9F_his_military_campaign_against_the_Ottoman_Empire_in_1462_and_the_forging_of_a_Romanian_ national_identity (accessed: 20 VII 2021).

${ }^{24}$ S. Andreescu, op. cit., pp. 46-47.

${ }^{25}$ Chalkokondyles, 9.104, p. 393 as quoted in M. Cazacu, op. cit., p. 158.

${ }^{26}$ By bringing Radu III the Handsome to power, the sultan resolved all his problems related to the insubordination of Vlad III the Impaler in Wallachia, without having to win a great military victory, plunder his own lands, or become involved in an unnecessary conflict with Hungary. C. S mith, op. cit., p. 15.

${ }^{27}$ During the Turkish invasion on Wallachia, Stephen III the Great tried to regain the Hungarian-Wallachian Kilia, an important Black Sea port which was 
finances) and other members of the anti-Turkish coalition, had to face the powerful Ottoman Empire alone. Vlad, despite vigorous defence, was finally captured in Piatra Craiului Mountains and extradited to Hungary in November 1462. Dracula's Transylvanian enemies, backed by king of Hungary, Matthias Corvinus ${ }^{28}$, falsely accused him of treason and anti-Hungarian plotting with Turkey, thus leading to his imprisonment. The behaviour of the Hungarian king is partly explained by the international situation at the time. Hungary was surrounded by enemies on all sides (including Emperor Frederick III who was aspiring to the Hungarian Crown, Stephen III the Great, or the Czech Hussite king, George of Podiebrad), so it did not decide to support Vlad against the Ottoman candidate for the Wallachian throne, as it would entail it in war with Turkey, a war that Hungary would have to fight alone. However, throughout 1463 the Hungarian king had to continuously explain why he had imprisoned Vlad III, and had abandoned the crusade against the Ottomans ${ }^{29}$.

Dracula in captivity, and then in exile, spent fourteen years, imprisoned at first at the castle in Buda and in Visegrád. A propaganda campaign began against him. A six-page pamphlet entitled The story of the voivode Dracula of 1463 was written in the form of a series of unrelated stories on atrocities committed by the Wallachian prince. For the next twelve years, Vlad the Impaler was transferred to Pest, where he resided with his wife and three children as a political prisoner of the Hungarian monarch. He was not allowed to leave the city, but enjoyed freedom and was receiving a salary ${ }^{30}$.

Meanwhile, the Hungarian-Turkish conflict has been suspended and Hungary lost the Danube affairs from its sight. In November 1473, Stephen III the Great threw Radu III the Handsome from

at that time a key to the further development of trade in the region. J. Demel, Historia Rumunii, Warszawa 1970, p. 129.

28 Matthias Corvinus was the second son of John Hunyadi. He was elected king of Hungary in 1458, a year after the death of Ladislaus V the Posthumous. W. Felczak, op. cit., p. 95.

${ }^{29}$ Dracula - historia prawdziwa, https://historiamniejznanaizapomniana. wordpress.com/2015/08/29/dracula-historia-prawdziwa/ (accessed: 25 VI 2021); C. Rezachevici, Punishment with Vlad Tepes - Punishments in Europe Common and Differentiating Traits, "Journal of Dracula Studies" 2006, vol. VIII, issue 1, p. 2.

${ }^{30}$ A. Michalewska, op. cit.; B.G. Sala, op. cit., p. 171. 
the throne and replaced him with Basarab III the Old. For over a year Wallachia passed from the hands of voivodes allied with Stefan the Great to the hands of Turkish vassals, and vice versa. Finally, at the end of 1474, Mehmed II decided to send his troops to Moldova to punish the rebellions. After the loss of the battle of Vaslui by the Turks in January 1475, in the spring of 1476, the sultan, supported by the Wallachian soldiers of Basarab III, set off with a retaliatory action at the head of a powerful army. As the Hungarian king was at that time busy with arranging his marriage to Beatrice of Aragon and negotiating with Frederick III, only the Transylvanian army, led by Stephen V Báthory of Ecsed and Vlad III Dracula, came to Moldova's help. Surprisingly, Turkey was forced to retreat, as the Ottoman army was decimated by the plague. It was then that the Transylvanian troops attacked the enemy's rear and won a victory in August 1476, as a result of which Vlad III managed to regain the Wallachian throne ${ }^{31}$.

Yet, already in December this year, Basarab III the Old returned, supported by the Turks, and defeated Vlad the Impaler, who orphaned a widow and three sons (Mihnea, probably Mircea, and Vlad). There is no consensus among historians about the circumstances of Dracula's death. The betrayal of the boyars is most often mentioned. Other sources say that the prince died when he went to the rescue of Stephen V Báthory, surrounded by Turkish troops. Finally, some believe that just before his final triumph in a battle, Dracula was killed by his soldiers. His scalped, embalmed, and cotton-stuffed head was sent to Istanbul, while his body was most likely buried in the Snagov Monastery, thirty-five kilometres from Bucharest, under the floor of the monastery church. Excavations at the beginning of the twentieth century did not confirm the existence of any human remains there. Only at a depth of three meters were the sarcophagus and coffin found. On contact with air, however, the body disintegrated immediately ${ }^{32}$.

${ }^{31}$ Already in 1475, Matthias Corvinus made the alliance treaty with Moldova against Turkey and decided to release prince Dracula and restore him to his former status of the voivode of Wallachia. However, the latter could not become the ruler of Wallachia at that time, because Basarab III had just made peace with Hungary, and maintained good relations with the Saxons, while paying tribute to the Turks. M. Cazacu, op. cit., pp. 180-184; J. Deme1, op. cit., p. 129.

${ }^{32} \mathrm{~K}$. Gonerski, op. cit. 


\section{The immortal legend of Dracula}

Even during the lifetime of Vlad III the Impaler, there were many legends about him. Some of them come from the years 1463-1464, i.e. the period immediately after his imprisonment by the Hungarians who tried to vilify the Wallachian voivode and thus, at least partially, justify his arrest. There are many stories from this period describing the incredible cruelty of Dracula, who did not hesitate to use such tortures as man cooking, cutting up, skinning or cutting off the ears, noses, limbs and genitals. His favourite method of killing, however, was the impalement, from which he owes his later nickname. Even at a time when public executions were the order of the day, death on a pale was considered one of the cruellest, as the victim died for up to three days, slipping slowly on the stake, which gradually tore its insides. According to various estimates, between 40,000 and 100,000 people were sentenced in this gruesome manner during the Impaler's rule, of which approx. 20,000 were exposed to the public in the capital city of Targovisste ${ }^{33}$.

Around 1475, when Dracula was to be restored to the Wallachian throne, the process of the prince's rehabilitation began. The stories circulating at that time emphasized the intransigent anti-Turkish attitude of the Wallachian ruler. Finally, in the years 1488-1521, about thirteen books, describing the cruelty of Vlad the Impaler, were published. However, it is difficult to unequivocally verify the truth of these stories. Thus, only those that were continuously repeated in various sources are presented below ${ }^{34}$.

In 1458, Matthias Corvinus sent a Pole, Benedict de Boithor, as an envoy to Wallachia. During the supper, Vlad Dracula ordered a golden spear to be placed exactly in front of the king's envoy, whom he asked if he knew why the spear had been placed there. Benedict replied that he suspected that a boyar had offended the prince, and that the latter wanted to reward him accordingly. When the voivode replied that the spear had been set up to honour the Polish guest, Benedict stated that if he had done anything to deserve death, the prince should do what he thought best. Dracula was very pleased to hear this answer and showered the envoy with

\footnotetext{
${ }^{33}$ K. Rozwadowski, op. cit.

${ }^{34}$ I. Czamańska, op. cit., p. 94.
} 
gifts. He did not hesitate to add, at the same time, that if the Pole had answered in any other manner, he would have been immediately impaled ${ }^{35}$.

According to another legend, Vlad the Impaler seized and confiscated all the possessions of merchants from Brasov and the land of Bârsy, impaling forty-one people. Then he gathered 300 young men from these areas, and having gathered them in one place, he impaled them or threw into the fire ${ }^{36}$. On the day of St Bartholomew in 1460, in turn, the cruel man ordered that 30,000 merchants and noblemen from the same city of Brassov be impaled, and he made a feast among impaled bodies. However, when, while eating, he noticed that one of his boyars was holding his nose, he ordered the sensitive nobleman to be impaled as well, but to be placed higher than the other bodies so that he would not feel the smell of all around him anymore ${ }^{37}$.

Once, two monks came from abroad to pay a visit to Vlad III in his palace in Targovisste. The ruler showed them his garden and rows of impaled bodies. When asked about their impressions, the first monk replied, "You are appointed by God to punish the evil-doers," while the second monk condemned the brutal prince. Then, Dracula rewarded the honest monk for his courage, and impaled the flatterer for insincerity. Another time, two envoys from the sultan came to the Wallachian voivode. When the prince asked them to take off the turbans, they refused. The angry voivode ordered them to be seized immediately and the turbans to be nailed to their heads ${ }^{38}$.

One of the legends, in turn, tells about a woman who always made every effort to lighten Dracula's burdens. Once she confessed to him that she was pregnant. The prince ordered to interrogate her, and when the woman's lie was revealed, he took a knife and cut her open from the groin to her breasts, while proclaiming his desire for the world to see where he had been. Voivode also was fighting disease and poverty in his own way. One day, he ordered a sumptuous feast for the paupers and the disabled. When they were eating and drinking to their heart's content, he ordered the

${ }^{35}$ S. Andreescu, op. cit., p. 82.

${ }^{36}$ C. Teodorescu, L.S. Szemkovics, R. Radu, op. cit., p. 59.

${ }^{37}$ S. Andreescu, op. cit., p. 82; M. Cazacu, op. cit., pp. 125, 136-137. p. 176.

${ }^{38}$ S. Andreescu, op. cit., p. 97; K. Gonerski, op. cit.; B.G. Sala, op. cit., 
shed to be set on fire, claiming that he had rendered these poor people a favour, because they were not happy when they were alive. He argued that he wanted to make Wallachia a well-managed land free from crime, where there would be room for healthy and resourceful people only ${ }^{39}$.

Although Dracula's rule was based on violence, the law he created was strictly respected by his countrymen. The effectiveness of the method of intimidating the society with severe penalties is evidenced by the fact that one day the prince placed a golden cup on the central square in Targovişte. The cup could be used by thirsty travellers, but it was to remain in its place forever. According to the legends, it has been never stolen indeed. Voivode also cared about the honesty of the merchants, whom he once forced to leave the stalls open for the night. Then he took a certain amount of money from each merchant, and during the day he asked each stallholder to state the exact amount that he had lost. If any of them dared to claim more than what was taken they ended up on a pale ${ }^{40}$.

Another story tells us about Dracula and his family's stay in Hungary. After Matthias Corvinus had freed him, Vlad III lived in Pest, in a house where one day a villain was looking for shelter. The people who were chasing him broke into the prince's house, who intervened and cut off the head of the guard chasing the criminal, while releasing the prisoner. When asked by the officials sent on behalf of the Hungarian king why he did so, Dracula was to answer the following: "I have done nothing wrong, but he has killed himself. All those who break into the house of a great sovereign as thieves shall likewise perish. If the mayor had come to me and had explained, and if I had found the criminal in my house, I would have delivered him myself or I would have spared him of his life"41.

Finally, with the exception of the folktale quoted below after Walter Langbein, in legends circulating about Vlad Țepess, there is practically no mention of its alleged vampirism: "Whenever a peasant or merchant family was to be impaled, simply because it had paid too little tax, Tepess would order the young daughter of that family to be brought to him - if there was one, but which usually happened - he tortured her, enslaved her, and finally ordered to

${ }^{39}$ S. Andreescu, op. cit., pp. 82, 96; I. Czamańska, op. cit., pp. 97-99.

${ }^{40}$ I. Czamańska, op. cit., p. 101; B.G. Sala, op. cit., p. 175.

${ }^{41}$ S. Andreescu, op. cit., p. 83. 
dagger her in front of him. Then, he would fill a cup with her blood and toast in front of her parents, dying on stakes" ${ }^{42}$.

On the other hand, taking into account the features of the literary character created by Bram Stoker, it should be concluded that the author of Dracula simply attributed to his title character all the attributes that were identified with vampires in folk beliefs ${ }^{43}$. This view is presented, among others, in the works of Elisabeth Miller and Anna Gemra, who clearly state that, apart from the name and cruelty, the most famous vampire in the world have very little in common with its historical prototype ${ }^{44}$.

\section{Conclusions}

It is difficult to unequivocally assess the reign of Vlad III the Impaler known as Dracula. It must be remembered that the times in which he reigned were turbulent. Manoeuvring between two military powers (Hungary and Turkey), he had numerous enemies both at home and abroad, with whom he often had to brutally deal with. The famous impalement was only one of the types of the death penalty, which was not inferior in its cruelty to breaking wheel, burning at the stake or drowning, so commonly used in Western Europe at that time ${ }^{45}$.

During the reign of Vlad Tepeş, Wallachia was probably inhabited by 300,000 people. The principality had over 2,000 cities and towns, seventeen cities were at the disposal of the ruler. However, these were not fortified castles, and in the event of an attack, the population had to escape into the surrounding forests. At the same time, due to the complicated international situation, the Wallachian voivode was left alone in the fight against the Ottoman Empire. No wonder he tried to create a modern state with effective law, healthy economy and strong central authority. However, this goal

${ }^{42}$ W.-J. La n g b e in, Największe tajemnice świata. Niezwykłe wydarzenia ostatnich XXV wieków, transl. E. Jurczyk, Katowice 1994, p. 132.

${ }^{43}$ According to P. Johnson, the folk tales circulating in Southern and Eastern Europe do not mantion the fact that vampires have no reflection in the mirror. See P. Johnson, op. cit., p. 11.

${ }^{44}$ E. Mille r, Filing for Divorce Count Dracula vs Vlad Tepes, [in:] Dracula: The Shade and the Shadow, a critical anthology ed. by eadem, Westcliff-on-Sea 1998, p. 179; A. Ge m ra, Od gotycyzmu do horroru: wilkołak, wampir i monstrum Frankensteina w wybranych utworach, Wrocław 2008, p. 163.

${ }^{45}$ C. Rezachevici, Punishment with..., pp. 6-7. 
was hindered by the boyar families, conspiring against him and supported by the Saxon patriciate of Transylvania, dissatisfied with the trade restrictions that Vlad Dracula imposed on foreign traders. Hence, among others, Dracula's decisions on the invasion and devastation of the Transylvanian Brassov (1457), as well as on the bloody settlements with boyars in 1459 .

It cannot be denied that the Wallachian prince was an effective and outstanding leader, who tried to defend the independence of his country with draconian methods. He even started minting his own coin, the so-called crusade ducat, that was supposed to help him pay for mercenaries in actions against the Turks. On the other hand, taking into account the fact that it is impossible to confirm the information about his alleged cruelty towards his own subjects, it should come as no surprise that to this day in the eyes of Romanians he is a national hero and a slayer of the Turkish invader ${ }^{46}$.

After having presented the most important facts from the life of Vlad III the Impaler, and the most often repeated legends about Dracula, as well as the polemic between researchers about the novel published by Bram Stoker in 1897, the following conclusions can be drawn. First of all, virtually none of the known tales of Vlad Tepeş mentions his alleged vampirism. Secondly, there is no convincing evidence that Bram Stoker, apart from using the name Dracula, modelled his literary character on a Wallachian voivode from the fifteenth century. The only undeniable fact is that, due to the legend of Dracula that has grown over the centuries, it is impossible to separate facts from myths on the life and deeds of the son of Vlad II the Dragon. In addition, thanks to the popularisation of the image of Dracula, also Vlad III himself has become immortal, although not in the same way as his literary counterpart ${ }^{47}$.

\footnotetext{
46 J. Deme1, op. cit., pp. 129-130.

${ }^{47}$ Bram Stoker introduced the concept of the un-dead to the English dictionary. Even before the novel was finally published in 1897, one version of its title was "Dracula; or, the Un-Dead". E. Miller, The Question of..., p. 2.
} 


\section{Bibliography}

\section{STudies}

Anderson J., Williams A., Head V., Rzezie, masakry i zbrodnie wojenne od starożytności do współczesności, transl. L. Hess, Warszawa 2009.

Andreescu S., Vlad Țepeş (Dracula). Intre legendă şi adevăr istoric, Bucharest 1998.

Baranowski B., W kręgu upiorów i wilkołaków, Łódź 1981.

Bartosiewicz A., Elisabeth Báthory - a true story, "Przegląd Nauk Historycznych" 2018, vol. XVII, No. 3, pp. 103-122.

Cawthorne N., 100 tyranów, despotów i dyktatorów, transl. A. Wiśniewska, Warszawa 2007.

Cazacu M., Drakula, $2^{\text {nd }}$ ed., transl. B. Biały, Warszawa 2021.

Czamańska I., Drakula, wampir, tyran czy bohater?, Warszawa 2013.

Demel J., Historia Rumunii, Warszawa 1970.

Felczak W., Historia Węgier, Wrocław-Warszawa-Kraków 1966.

Florescu R., McNally R., Dracula: A Biography of Vlad the Impaler, New York 1973.

Gemra A., Od gotycyzmu do horroru: wilkołak, wampir i monstrum Frankensteina w wybranych utworach, Wrocław 2008.

Gerard E., Transylvanian Superstitions, “The Nineteenth Century”1885, vol. XVIII, pp. 128-144.

Grabias M., Dracula - nowe perspektywy badawcze (recenzja), "Perspektywy Kultury" 2019, No. 25, pp. 193-198.

Humphreys C.C., Wład Palownik: prawdziwa historia Drakuli, transl. U. Gardner, Warszawa 2012.

Hupchick D., Cox H., The Palgrave Concise Historical Atlas of the Balkans, New York 2001.

Johnson P., Count Dracula and the Folkloric Vampire: Thirteen Comparisons, "Journal of Dracula Studies" 2001, vol. III, issue 1, pp. 1-12.

Langbein W.-J., Największe tajemnice świata. Niezwykłe wydarzenia ostatnich XXV wieków, transl. E. Jurczyk, Katowice 1994.

Marcu A., Riflessi di storia rumena in opere italiane dei secoli XVI e XV, "Ephemeris Dacoromana” 1923, vol. I, pp. 371-375.

McNally R.T., Florescu R., In Search of Dracula: A True History of Dracula and Vampire Legend, Greenwich 1972.

Melton J.G., Hornick A., The Vampire in Folklore, History, Literature, Film and Television. A Comprehensive Bibliography, Jefferson, NC 2015.

Miller E., Filing for Divorce Count Dracula vs Vlad Tepes, [in:] Dracula: The Shade and the Shadow, a critical anthology ed. by E. Miller, Westcliff-on-Sea 1998, pp. 1-7.

Miller E., The Question of Immortality: Vampires, Count Dracula, and Vlad the Impaler, "Journal of Dracula Studies" 2002, vol. IV, issue 1, pp. 1-7.

Reychman J., Historia Turcji, Wrocław 1973. 
Rezachevici C., From the Order of the Dragon to Dracula, "Journal of Dracula Studies" 1999, vol. I, issue 1, pp. 1-6.

Rezachevici C., Punishment with Vlad Tepes - Punishments in Europe Common and Differentiating Traits, "Journal of Dracula Studies" 2006, vol. VIII, issue 1, pp. 1-13.

Robotycki C., Wampiry. Od wierzeń ludowych do filmowych fantomów, "Konteksty" 1992, No. 3-4, pp. 148-149.

Sala B.G., W górach przeklętych. Wampiry Alp, Rudaw, Sudetów, Karpat i Bałkanów, Olszanica 2016.

Stoicescu N., Vlad Tepes' Relations with Transylvania and Hungary, [in:] Dracula. Essays on the Life and Times of Vlad the Impaler, ed. K.W. Treptow, New York 1991, pp. 81-101.

Stoker B., Dracula, Hertfordshire 2000.

Stoker B., Dracula's Guest and Other Stories, Hertfordshire 2006.

Strzelczyk J., Mity, podania i wierzenia dawnych Słowian, Poznań 1998.

Teodorescu C., Szemkovics L.S., Radu R., From Vlad Țepeş-Wallachian ruler - to Dracula. Conclusive documents regarding his name and "fame", "Quaestus. Multidisciplinary Research Journal" 2018, No. 12, pp. 55-68.

Torz M., Od wołoskiego hospodara po ikone popkultury, "Archeologia Żywa" 2018, No. 4(70), pp. 68-74.

Treptow K.W., Vlad III Dracula: the Life and Times of the Historical Dracula, Portland 2000.

Vorsino M., The Dragon, the Raven and the Ring, "Journal of Dracula Studies" 2003, vol. V, issue 1, pp. 1-6.

Zych P., Vargas W., Bestiariusz słowiański. Część pierwsza i druga, Olszanica 2018.

\section{NeTOGRAPHY}

Dan P., Psycho-biographical considerations about Vlad the Impaler also known as Dracula, https://www.academia.edu/10342218/Psycho-biographical_considerations _about_Vlad_the_Impaler_also_known_as_Dracula (accessed: 19 VII 2021).

Dracula - historia prawdziwa, https://historiamniejznanaizapomniana.wordpress.com/2015/08/29/dracula-historia-prawdziwa/ (accessed: 25 VI 2021).

Gonerski K., Vlad Tepes: prawdziwa historia Ksiecia Draculi, http://www.horror. com.pl/publicystyka/art.php?id=62 (accessed: 1 VII 2021).

Hrabia Dracula - nieśmiertelna legenda, https:/ /lo.tarnobrzeg.pl/lesser/artykuly/ hrabia-dracula-niesmiertelna-legenda (accessed: 13 VI 2021).

Ksiażę Dracula wampirem? Historia prawdziwa, https://minds.pl/artykul/ksiazedracula-wampirem-historia-prawdziwa (accessed: 19 VII 2020).

Michalewska A., Vlad Palownik. Prawdziwy Drakula, https://www.granice.pl/ publicystyka/wlad-palownik-vlad-drakula-dracula-historia-prawdziwa/ 1134/ 1 (accessed: 15 VII 2021).

Rozwadowski K., Wład III Palownik-Dracula, https:/ / historia.org.pl/2009/10/05/ wlad-iii-palownik-dracula/ (accessed: 1 VII 2021). 
Sanecki T., Dracula wampirem? Kim naprawde był Vlad Tepes?, http://mojhistorycznyblog.pl/dracula-wampirem-kim-naprawde-byl-vlad-tepes (accessed: 5 VII 2021).

Smith C., Vlad Țepeş, his military campaign against the Ottoman Empire in 1462, and the forging of a Romanian national identity, https://www.academia. edu/25642701/Vlad_\%C5\%A2epe\%C5\%9F_his_military_campaign_against_ the_Ottoman_Empire_in_1462_and_the_forging_of_a_Romanian_national_ identity (accessed: 20 VII 2021).

Vlad Tepes: Tyrant or Misunderstood?, https: / / owlcation.com/humanities/VladTepes-Tyrant-or-Misunderstood (accessed: 22 VI 2021).

About the Author:

PhD Aleksandra Bartosiewicz - doctor of economics, currently works as an adjunct in the Department of Operational Research of the Institute of Logistics and Computer Science at the Faculty of Economics and Sociology of the University of Lodz. Author of, among others, articles on the history of the container shipping, of the stock exchange, and on the biographies of famous historical characters.

Research interest: logistics and transportation, maritime container transport, cinema distribution market, market analysis, history of containerisation, history of stock exchange, biographies of famous people.

( 